\title{
Gastrin-induced proliferation involves MEK partner 1 (MP1)
}

\author{
Tonje S. Steigedal • Wenche S. Prestvik • \\ Linn-Karina M. Selvik • Christina S. Fjeldbo • \\ Torunn Bruland • Astrid Lægreid • Liv Thommesen
}

Received: 9 November 2012 / Accepted: 30 January 2013 /Published online: 14 February 2013 / Editor: T. Okamoto

(C) The Author(s) 2013. This article is published with open access at Springerlink.com

\begin{abstract}
The peptide hormone gastrin is an important factor for the maintenance and homeostasis of the gastric mucosa. We show that gastrin stimulates proliferation in a dose-dependent manner in the human gastric adenocarcinoma cell line AGS- $G_{R}$. Furthermore, we demonstrate that the MAPK scaffold protein MEK partner 1 (MP1) is important for gastrin-induced phosphorylation of ERK1 and ERK2 and that MP1 promotes gastrin-induced proliferation of AGS- $G_{R}$ cells. Our results suggest a role of MP1 in gastrin-induced cellular responses involved in proliferation and homeostasis of the gastric mucosa.
\end{abstract}

Keywords Gastrin · Gastrointestinal proliferation · Tissue homeostasis $\cdot$ Scaffold protein $\cdot$ MAPK/ERK pathway · MAP2K1IP1 · MAPK scaffold protein $1 \cdot$ MAPKSP1 . MEK-binding partner $1 \cdot$ Mitogen-activated protein kinase kinase 1-interacting protein $1 \cdot$ Mitogen-activated protein kinase scaffold protein $1 \cdot$ Late endosomal/lysosomal adaptor and MAPK and MTOR activator $3 \cdot$ LAMTOR3

\section{Introduction}

The peptide hormone gastrin plays a central role in gastric acid secretion (Edkins 1906), differentiation of the gastric mucosa (Koh et al. 1997), maintenance, homeostasis, and epithelial organization of the cells in the gastric mucosa

T. S. Steigedal $(\varangle) \cdot$ L.-K. M. Selvik $\cdot$ C. S. Fjeldbo • T. Bruland • A. Lægreid $\cdot$ L. Thommesen

Department of Cancer Research and Molecular Medicine, Norwegian University of Science and Technology (NTNU), Postbox 8909, 7491 Trondheim, Norway

e-mail: tonje.strommen@ntnu.no

W. S. Prestvik • L.-K. M. Selvik • L. Thommesen Department of Technology, Sør-Trøndelag University College, Trondheim, Norway
(Dockray et al. 2001). In addition to its role in regulation of normal physiological processes, gastrin may also be an important player in gastric carcinogenesis (Watson et al. 2006). Gastrin is shown to exert growth-promoting effects in both normal and malignant gastrointestinal tissues like the oxyntic mucosa (Wang et al. 1996) and gastric epithelial cells (Wang et al. 2000). Several studies have demonstrated that gastrin stimulates growth of human gastric cell lines (Ishizuka et al. 1992), pancreatic cell lines (Seva et al. 1990; Smith et al. 1994), and human and mouse colonic tumors (Smith et al. 1993). Interestingly, Varro et al. (2002) have used a co-culture system to show that gastrin causes suppression of proliferation in cells expressing the gastrin receptor, CCK2R, and a subsequent activation of proliferation in cells that do not express these receptors. They demonstrate that these signals are transferred via paracrine activation of the epidermal growth factor receptor (Varro et al. 2002). However, the growth-regulatory mechanisms are complex since gastrin also has been found to have both growth-promoting and inhibitory effects in different cells and cell lines expressing CCK2R (Smith et al. 1994; Seufferlein et al. 1995; Detjen et al. 1997a, b; Muerkoster et al. 2005). In addition to its growth-promoting effects, gastrin may also induce oncogenic transformation via increased cell migration (Noble et al. 2003), invasion (Wroblewski et al. 2002), and circumvention of apoptosis (Todisco et al. 2001; Fjeldbo et al. 2012). The ambiguous responses to gastrin indicate that gastrin plays pivotal roles in the regulation of many cellular processes, and the overall response to gastrin is governed by multiple intricate mechanisms.

To investigate the molecular mechanisms underlying gastrin-mediated cellular responses in a genome-wide approach, we carried out several time-series gene expression microarray studies covering the first 14-24 h of gastrin response in rat pancreatic AR42J cells. The studies identify a number of gastrin-responsive genes, many of which have 
not previously been described to be regulated by gastrin (EMTAB-123 and GSE32869). In the present study, we focus on one of the new gastrin target genes based on its possible roles in cellular proliferation: Mitogen activated protein kinase kinase 1 interacting protein 1 (Map2k1ip1, MEK partner 1, Lamtor3, or MP1).

MP1 was first identified as a scaffold protein enhancing the efficiency of the MAPK pathway by facilitating the interaction between MEK1 and ERK1 upon serum stimulation (Schaeffer et al. 1998). Later, it has been demonstrated that MP1 enhances activation of both ERK1 and ERK2 as a response to EGF (Teis et al. 2002) and fibronectin (Pullikuth et al. 2005). MP1 is recruited to late endosomes by the adaptor protein p14 (Teis et al. 2002), and the protein complex p14-MP1-MEK1 is involved in regulating endosomal trafficking and cellular proliferation during tissue homeostasis (Teis et al. 2006). MP1 has also been found to regulate cell spreading by integrating PAK1 and Rho signals (Pullikuth et al. 2005). A recent report has unmasked a novel lipid raft adaptor on late endosomes, p18, which controls endosome dynamics by anchoring p14-MP1 in complex with MEK1 and ERK1 to the membranes of late endosomes (Nada et al. 2009). The present study demonstrates that gastrin induces proliferation in a dose-dependent manner and suggests a role of MP1 in regulation of proliferation via CCK2R and ERK1/2 signaling in gastric epithelial AGS-G $\mathrm{G}_{\mathrm{R}}$ cells.

\section{Materials and Methods}

Cells and reagents. AGS (human gastric adenocarcinoma, ATCC, Rockville, MD) and AGS-G $\mathrm{G}_{\mathrm{R}}$ cells (AGS stably transfected with the CCK2 receptor (Watson et al. 2001; Varro et al. 2002); gift from Prof. A. Varro, University of Liverpool, England) were grown in Ham's F12 (Invitrogen, Carlsbad, CA) supplemented with $10 \%$ fetal calf serum (FCS; Euroclone, Devon, UK), 10 U/ml penicillin-streptomycin (Invitrogen), and $2 \mu \mathrm{g} / \mathrm{ml}$ puromycin (Sigma Chemical, St. Louis, MO) (AGS-GR cells). AR42J (rat pancreatic acinar cell-derived; ATCC) were grown in DMEM with $4.5 \mathrm{~g} / 1$ glucose (Invitrogen), 15\% FCS, $1 \mathrm{mM}$ sodium pyruvate (Invitrogen), $0.1 \mathrm{mg} / \mathrm{ml} \mathrm{L-glutamine} \mathrm{(Invitrogen),}$ $10 \mathrm{U} / \mathrm{ml}$ penicillin/streptomycin (Invitrogen), and $1 \mu \mathrm{g} / \mathrm{ml}$ fungizone (Invitrogen). Gastrin-17 was purchased from Sigma.

$x$ CELLigence proliferation assay. Adherent cell proliferation was measured in a label-free, real-time manner using xCELLigence Technology. This system utilizes specialized culture plates that contain gold electrode arrays at the bottom of individual wells (Roche Applied Science). Cellular contact with the electrode surfaces increases the impedance across these gold arrays. This impedance value is measured by the RTCA SP system and is reported in the dimensionless unit of cell index. The day before seeding, sub-confluent cells were split 1:2 in order for cells to be in exponential growth phase at the time of seeding for xCELLigence analysis. Prior to seeding of cells in the 96well E-plate, $50 \mu \mathrm{l}$ plain medium was added to wells, and background read was recorded. Wild-type AGS and AGS$\mathrm{G}_{\mathrm{R}}$ cells were split, and $5 \times 10^{4}$ cells in $100 \mu \mathrm{l}$ medium were added to each well. Finally, $50 \mu$ medium containing gastrin to 0.1-100 $\mathrm{nM}$ or $100 \mathrm{ng} / \mathrm{ml}$ human recombinant EGF (Sigma) final concentration in either absence or presence of $10 \%$ serum was added to the cells. Real-time monitoring of cell proliferation measured as cell index was recorded every $5 \mathrm{~min}$ for up to $70 \mathrm{~h}$.

Real-time RT-PCR. Total RNA from 6-well plates was isolated using RNeasy Mini kit (Qiagen, Germantown, MD) according to the manufacturer's protocol. cDNA synthesis was performed with $1 \mu \mathrm{g}$ of total RNA in a $20-\mu 1$ reaction of Reverse-iT First Strand Synthesis kit according to the manufacturer's instruction (Abgene, Rockford, IL). After synthesis, the cDNA was diluted 1:4 with RNase-free water. SYBR Green real-time PCR was run in $1 \mathrm{x}$ ABsolute ${ }^{\mathrm{TM}}$ QPCR SYBR ${ }^{\circledR}$ Green Mix (Abgene) with $70 \mathrm{nM}$ of each primer and cDNA equivalent to $31.3 \mathrm{ng}$ total RNA. Real-time PCR was performed in Stratagene's Mx3000P real-time PCR system: $15 \mathrm{~min}$ at $95^{\circ} \mathrm{C}, 40$ thermal cycles of $15 \mathrm{~s}$ at $95^{\circ} \mathrm{C}, 1 \mathrm{~min}$ at $56-60^{\circ} \mathrm{C}$, and $30 \mathrm{~s}$ at $72^{\circ} \mathrm{C}$. PCR products were verified by a dissociation curve analysis to confirm primer specificity. PCR products were analyzed on agarose gels. Fold induction levels were calculated using the $\Delta \Delta$ Ct-method (Livak and Schmittgen 2001).

Primer sequences. Human-MP1 S: 5'-ACCAGGTG GTTCAATTTAATCG-3', human-MP1 AS : 5'CTTCAAACAATGGAGCAAGTTC-3', human-GAPDH S: 5'-TCTGACTTCAACAGCGACACC-3', humanGAPDH AS: 5'-TGTTGCTGTAGCCAAATTCGT-3', ratMP1 S: 5'-AAGTTGCCAAGCGTTGAAGG-3', rat-MP1 AS: 5'-GGCGAAAGTGGACAAGAAG-3', rat $\beta$-actin S: 5'-CTGGCTCCTAGCACCATGA-3', and rat $\beta$-actin AS: 5'-AGCCACCAATCCACACAGA-3'.

RNA interference experiments. For transfection with siRNAs, AGS-G $\mathrm{G}_{\mathrm{R}}$ cells $\left(2 \times 10^{5}\right)$ were seeded in 6-well plates. The cells were transfected $24 \mathrm{~h}$ after seeding using $2.5 \mu \mathrm{g}(81 \mathrm{nM})$ siRNA and $12.5 \mu \mathrm{l}$ Metafectene $^{\mathrm{TM}}$ PRO (Biontex, Martinsried/Planegg, Germany) diluted in Ham's F12 in accordance with manufacturer's protocol. Cells were transfected for $24-48 \mathrm{~h}$ before further processing.

siRNA oligonucleotides. Human siRNA oligonucleotides were purchased from Ambion (Carlsbad, CA): siMP1 
(ID\#138573), siCycD1 (ID\#42828), and Silencer Negative Control siRNA\#1 (siCtr).

Western blot analysis. Cells growing in 6-well plates were harvested and subjected to western blot analysis as described previously (Steigedal et al. 2007). Binding of secondary antibodies was visualized by the SuperSignal West Femto detection system (Pierce, Rockford, IL) and Kodak Image Station 2000R (Kodak, Pittsburgh, PA). The following antibodies were used: rabbit anti-mouse MP1 (gift from Prof. A. Catling), mouse anti human p-ERK1/2 (Santa Cruz Biotechnology, Santa Cruz, CA), mouse anti-human $\beta$-actin (Abcam, Cambridge, UK), rabbit anti-human GAPDH (Santa Cruz), HRP-conjugated goat anti-rabbit IgG (Cell Signaling, Danvers, MA), and HRP-conjugated goat antimouse (Dako, Glostrup, Denmark).

Flow cytometry. Cells $\left(2 \times 10^{5}\right)$ were seeded in 6-well plates and transfected the following day. Twenty-four hours after transfection, the cells were treated with $10 \mathrm{nM}$ gastrin without medium replacement. The cells were stimulated for $24 \mathrm{~h}$ before they were harvested and subjected to cell cycle analysis according to a modified version of the Vindelov protocol (Vindelov et al. 1983) using $416 \mathrm{ng} / \mu \mathrm{l}$ propidium iodide (Sigma). The nuclei were filtered through a $40-\mu \mathrm{m}$ nylon mesh and subjected to a BD FACS LSRII flow cytometer (BD Biosciences). Cell cycle data was analyzed in FlowJo 7.5 (Tree Star Inc., Ashland, OR).

Statistical analysis. xCELLigence proliferation assays were performed three times with four technical replicates in each experiment. The data is represented as mean $\pm \mathrm{SD}$. Quantitative RT-PCRs were run three times, with three technical replicates in each run and data presented as mean \pm SD. Flow cytometry experiments were performed three times and data presented as mean $\pm \mathrm{SD}$.

\section{Results}

Gastrin stimulates proliferation in a dose-dependent manner in human $A G S-G_{R}$ cells. Gastrin may mediate proliferation, differentiation, or apoptosis depending on cell type, tissue, and organ (Seva et al. 1990; Ishizuka et al. 1992; Smith et al. 1993, 1994; Wang et al. 1996; Detjen et al. 1997a, b; Wang et al. 2000; Varro et al. 2002; Muerkoster et al. 2005). We wanted to employ the gastric cell line AGS- $G_{R}$, overexpressing CCK2R, to study mechanisms involved in gastrin-mediated proliferation. Reports in the literature are conflicting with regard to the ability of gastrin to induce proliferation in cell lines. Varro et al. (2002) observed an inhibitory effect of gastrin-mediated proliferation on AGS- a

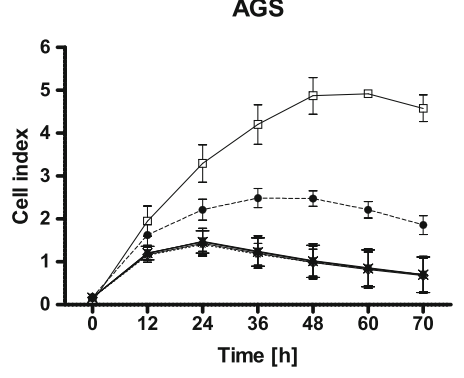

b
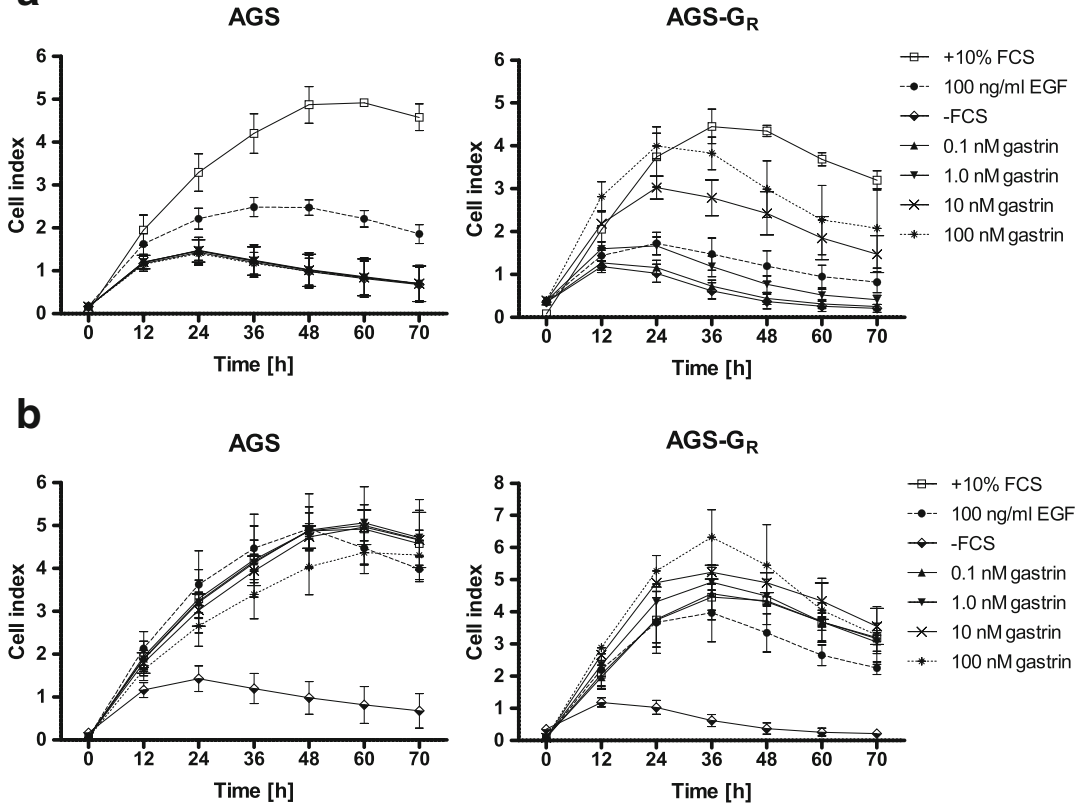

AGS-G $G_{R}$

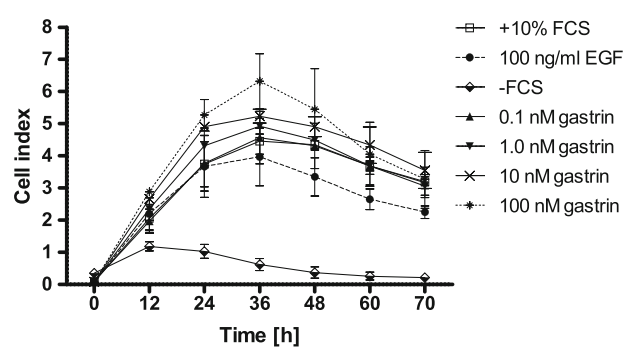

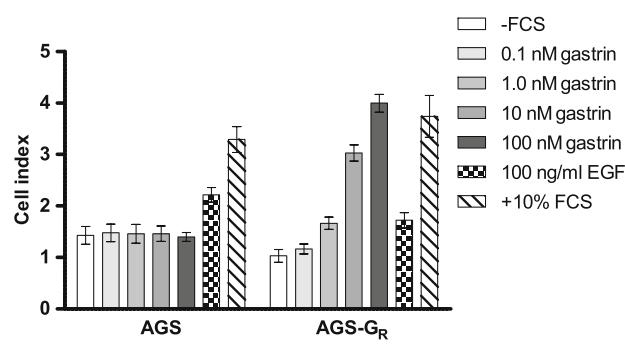

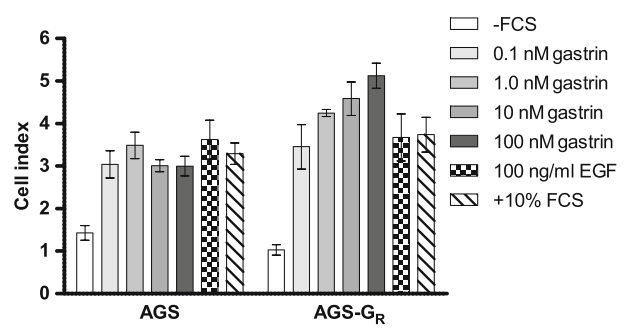

Figure 1. xCELLigence proliferation assay of wild-type AGS and AGS- $G_{R}$ cells in response to gastrin. AGS and AGS- $G_{R}$ cells were seeded in 96-well E-plates for xCELLigence assay monitoring impedance (cell index). The cells were treated with either $10 \%$ FCS or $100 \mathrm{ng} / \mathrm{ml} \mathrm{EGF}$ as controls or gastrin at different concentrations $(0.1$, 1,10 , or $100 \mathrm{nM}$ ) in either absence or presence of serum. (a) Complete growth curves of AGS and AGS-G $\mathrm{G}_{\mathrm{R}}$ cells from 0 to $70 \mathrm{~h}$ after seeding.
The cells were treated with gastrin and EGF in absence of serum. Panel to the right shows bar graph of cell index at $24 \mathrm{~h}$ growth. (b) Complete growth curves of AGS and AGS- $\mathrm{G}_{\mathrm{R}}$ cells from 0 to $70 \mathrm{~h}$ after seeding. The cells were treated with gastrin and EGF in presence of serum. Panel to the right shows bar graph of cell index at $24 \mathrm{~h}$ growth. Data is represented as mean $\pm \mathrm{SD}$ of three independent experiments. 
$\mathrm{G}_{\mathrm{R}}$ cells. There are also reports demonstrating both stimulation and inhibition of proliferation via CCK2R in AR42J cells (Bestervelt et al. 2000; Hofsli et al. 2002). Using the relatively new xCELLigence technology, we were able to study the complete proliferative response to gastrin in a realtime manner. We investigated the effect of gastrin in cells subjected to a variety of stimulation conditions. AGS- $G_{R}$ cells were treated with several different gastrin concentrations in either absence (Fig. 1a) or presence (Fig. 1b) of serum, and proliferation was measured with real-time cell index as output. We observed a dose-dependent proliferative effect when cells were treated with gastrin both in absence and presence of serum. This finding demonstrates that gastrin enhances proliferation in actively growing $A G S-G_{R}$ cells. Wild-type AGS cells (without CCK2R) did not show any response to gastrin, suggesting that the observed effect was mediated via the CCK2R. We (Hofsli et al. 2002) and others (Bestervelt et al. 2000) have previously shown that gastrin promotes proliferation of AR42J cells, and Varro et al. (2002) have shown a growth inhibitory effect of gastrin in $A G S-G_{R}$ cells. Our findings are in keeping with the assumption that gastrin exhibits both proliferative and antiproliferative properties depending on the cell type as well as the cell state at the onset of gastrin treatment, but the assay for monitoring proliferation may also be important as realtime monitoring gives a better picture than classical endpoint proliferation assays.

Gastrin induces expression of MP1 in both AR42J and AGS$G_{R}$ cells. Our whole genome microarray gene expression screening indicated that the gastrin-responsive gene $M P 1$ is an early response primary gastrin target gene that is upregulated within $4 \mathrm{~h}$ after onset of gastrin treatment in pancreatic AR42J cells (E-MTAB-123 and GSE32869). In order to validate the time profile observed by microarray analysis, expression of MP1 was measured by quantitative RT-PCR. The results showed increasing MP1 levels up to $2 \mathrm{~h}$ of gastrin treatment, followed by sustained mRNA levels up to $6 \mathrm{~h}$ in AR42J cells (Fig. 2a). In AGS-G $\mathrm{G}_{\mathrm{R}}$ cells, the peak expression for MP1 was at $4 \mathrm{~h}$ followed by a rapid decrease (Fig. 2b). MP1 protein expression assessed by Western blot in AGS- $\mathrm{G}_{\mathrm{R}}$ cells showed a continuous increase up to 8-10 h
Figure 2. Gastrin-mediated activation of MP1 in AR42J and AGS-G $\mathrm{G}_{\mathrm{R}}$ cells. (a) Verification of gene expression microarray results with quantitative RT-PCR in AR42J. Cells were seeded in 6-well plates and serum starved for $24 \mathrm{~h}$ the following day prior to treatment with gastrin $(10 \mathrm{nM})$ as indicated in figure. (b) Quantitative RT-PCR analysis of MP1 expression in AGS-G $G_{R}$. Cells were seeded in 6-well plates and cultivated $24 \mathrm{~h}$ prior to gastrin treatment $(10 \mathrm{nM})$ as indicated in figure. Fold induction levels were calculated using the $\Delta \Delta$ Ct-method (Livak and Schmittgen 2001), where the expression levels were normalized to the level of $\beta$-actin (AR42J) or GAPDH (AGS-G ${ }_{\mathrm{R}}$ ) expression, and gastrin-treated cells were compared to untreated cells. One representative experiment is shown and data presented as mean $\pm \mathrm{SD}$ of three technical replicates. (c) Western blot of AGS-G $\mathrm{G}_{\mathrm{R}}$ lysates from cells treated with $10 \mathrm{nM}$ of gastrin

$2-10 \mathrm{~h}$ before harvesting. The blot was treated with non-commercial antibodies against MP1, and $\beta$-actin was used as loading control. Lower panels show relative quantification of band intensities from western blot analysis. a

RT PCR AR42J

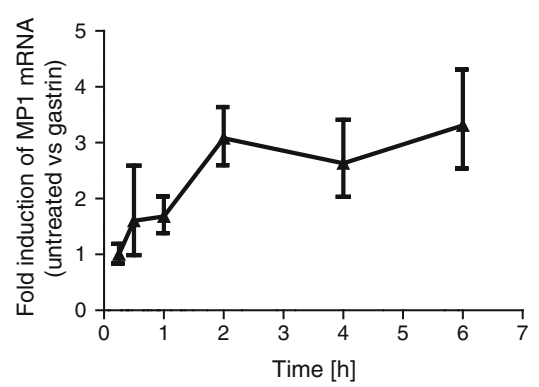

C
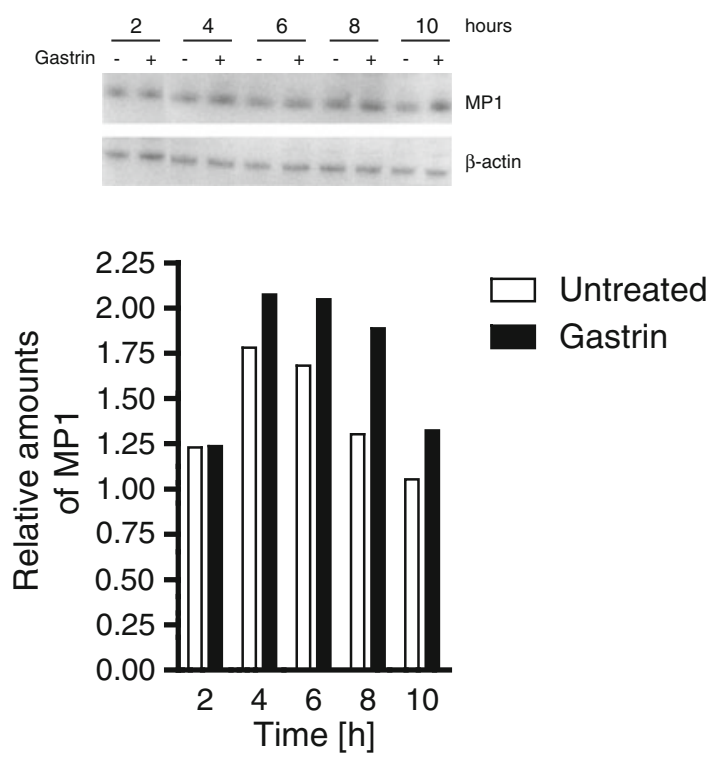

b

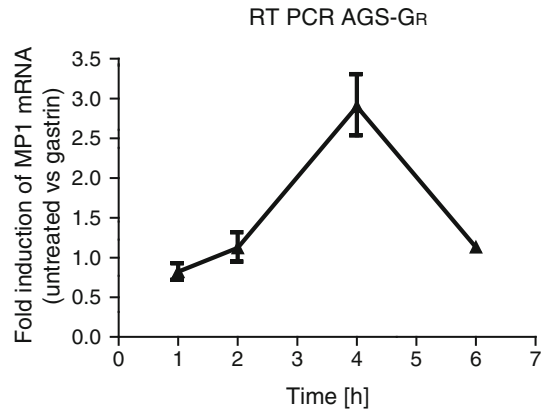


of gastrin treatment (Fig. 2c). Together, these results demonstrate that MP1, previously not described in the gastrin response, is induced by gastrin in a relatively comparable manner in both AR42J and AGS-G $\mathrm{G}_{\mathrm{R}}$ cells.

MP1 is essential for gastrin-induced phosphorylation of ERK1 and ERK2. MP1 has been shown to be involved in activation of both ERK1 and ERK2 (Schaeffer et al. 1998; Teis et al. 2002; Pullikuth et al. 2005). Since gastrin is known to induce phosphorylation of ERKs (Seufferlein et al. 1995; Todisco et al. 1995), it was of interest to investigate the functional role of MP1 in the gastrin response. We therefore assessed gastrin-induced phosphorylation of ERK1 and ERK2 in AGS-G $G_{R}$ cells in the presence or absence of siRNA targeting MP1. The results showed that in cells treated with siMP1, gastrin induced markedly lower levels of both ERK1 and ERK2 phosphorylation compared to cells treated with control siRNA at all time-points analyzed (Fig. 3a). Densiometric measurements using GAPDH as control verified this finding (Fig. $3 b, c$ ). The results demonstrate for the first time that MP1 is involved in gastrin-induced activation of the MAPK pathway. This finding supports our hypothesis that MP1 is an important factor in gastrin-induced activation of processes downstream of the MAPK pathway.

MP1 promotes gastrin-induced proliferation. The MAPK pathway is central for cell proliferation (Hill and Treisman 1995). Since MP1 enhanced gastrin-induced activation of ERK1 and ERK2, and gastrin-mediated signaling is shown to be transduced via the MAPK pathway (Stepan et al. 1999), we investigated whether MP1 may be involved in gastrin-induced cell cycle regulation. We performed cell cycle analysis using flow cytometry on AGS- $\mathrm{G}_{\mathrm{R}}$ cells in the presence or absence of siMP1. siCycD1 was included as a positive control since Cyclin D1 is known to be required for G1/S transition (Baldin et al. 1993). The cell cycle profile in siCycD1-treated cells showed, as expected, a lower proportion of S-phase cells compared to controls in both untreated and gastrin-treated cells $(20.2 \%$ and $24.3 \%$, respectively; Fig. 4). Similarly, MP1 depletion induced G1 cell cycle arrest in both untreated and gastrin-treated cells. The proportion of S-phase cells in gastrin-treated siMP1transfected samples versus siCtr-transfected was $22.5 \%$ and $31.7 \%$, respectively. In untreated cells, the proportion was $20.0 \%$ (siMP1) and $26.6 \%$ (siCtr). For all siRNA treatments, we observed that gastrin was a strong enhancer of proliferation, and neither siCycD1 nor siMP1 treatment was able to circumvent this effect, as reflected in the fact that the overall fold change of cells in S-phase before and after gastrin treatment was not altered in cells treated with siMP1 or siCycD1 compared to controls. Our results showing that MP1 depletion induces G1 cell cycle arrest to a

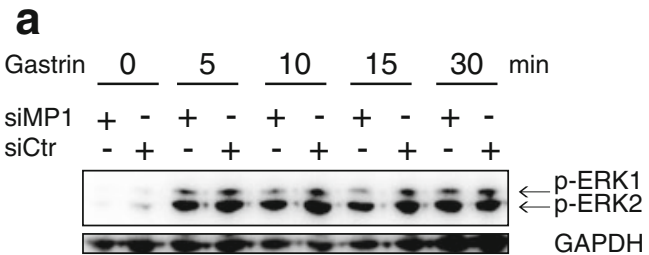

b
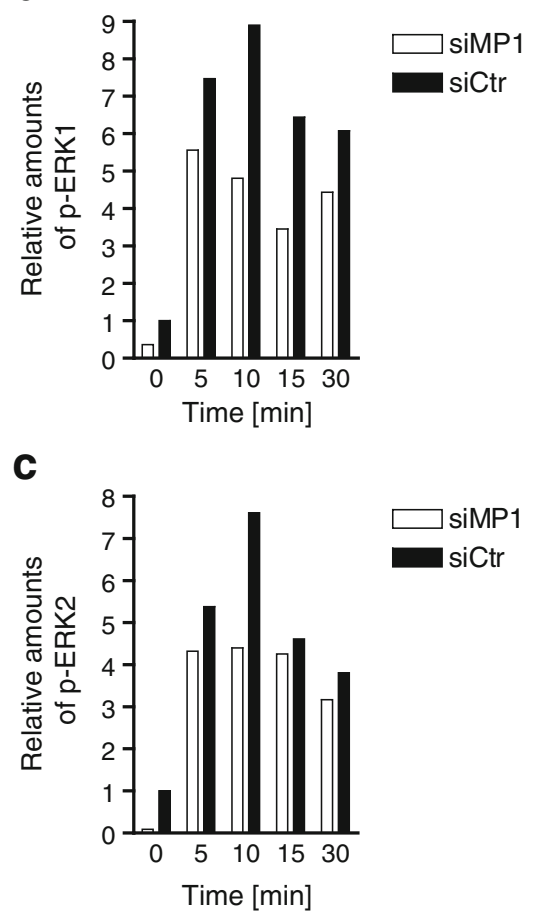

Figure 3. MP1 depletion reduces gastrin-induced phosphorylation of ERK1 and ERK2 (p-ERK1/2). (a) AGS-G $\mathrm{R}_{\mathrm{R}}$ cells were transfected with siMP1 and siCtr for $24 \mathrm{~h}$. Then, the cells were serum starved for $24 \mathrm{~h}$ and treated with $10 \mathrm{nM}$ gastrin for 5 to $30 \mathrm{~min}$ before harvesting. Protein extracts were subjected to SDS-PAGE and analyzed for $\mathrm{p}$ ERK1 and p-ERK2 in addition to GAPDH (loading control). $(b, c)$ Densiometric analysis of relative amounts of p-ERK1 and p-ERK2, respectively. One representative experiment is shown. Similar results were obtained three times.

similar extent as Cyclin D1 depletion indicate that MP1 plays a role in regulation of proliferation, but this effect is not restricted to proliferation induced by gastrin. The fact that single-gene knockdown of essential cell cycle genes does not halt proliferation is in keeping with other studies (Kozar and Sicinski 2005).

\section{Discussion}

The purpose of the present study was to enhance our knowledge of molecular mechanisms by which gastrin regulate proliferation. Gastrin has been shown to display proliferative, anti-apoptotic, and anti-proliferative properties, dependent on 

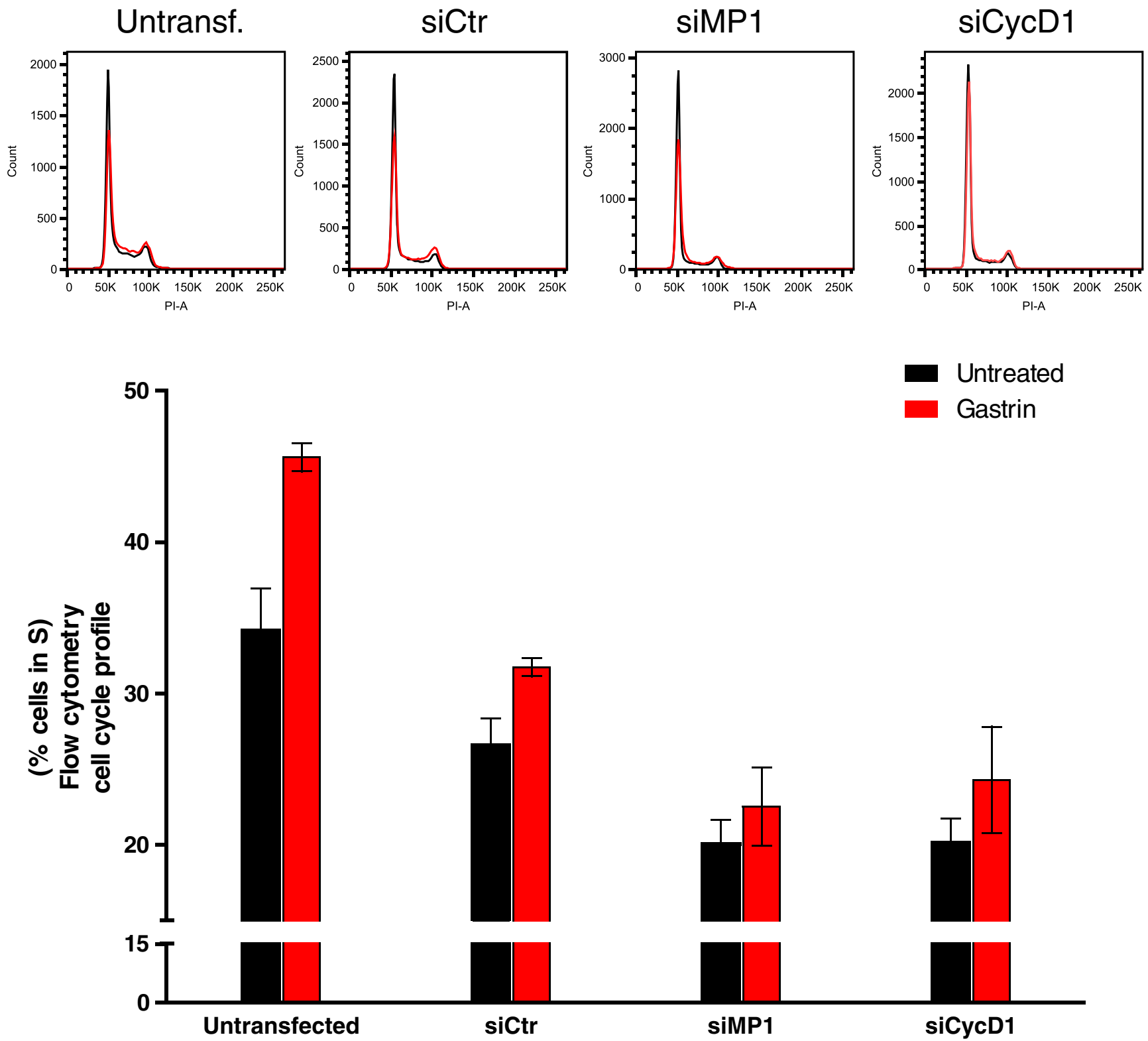

Figure 4. MP1 enhances cell cycle progression. $A G S-G_{R}$ cells were grown and treated with siCtr, siMP1, or siCycD1. Cells were treated with $10 \mathrm{nM}$ gastrin without medium replacement $24 \mathrm{~h}$ after transfection and then grown for another $24 \mathrm{~h}$. Finally, the cells were harvested in citrate buffer and treated with buffers $\mathrm{A}, \mathrm{B}$, and $\mathrm{C}$ according to a slightly modified version of the Vindelov protocol (Vindelov et al.

cell type, tissue, or context (Yassin 1999; Dockray et al. 2005; Watson et al. 2006; Dimaline and Varro 2007; Grabowska and Watson 2007). We show that gastrin induces proliferation in AGS- $\mathrm{G}_{\mathrm{R}}$ cells in a dose-dependent manner. We recently identified $M P 1$ to be among a large number of new gastrin target genes (E-MTAB-123 and GSE32869), many of which may be involved in gastrin-mediated proliferation. Here, we show that MP1 is necessary for gastrin-induced phosphorylation of ERK1 and ERK2 and that it may be involved in mediating gastrin-induced proliferation of $A G S-G_{R}$ cells. The present
1983). The proportion of cells in S-phase of the cell cycle in untreated (black) and gastrin-treated (red) bars. DNA histograms were created from 20,000 propidium iodide stained nuclei. Representative histograms are shown, and data is presented as percent cells in S-phase mean $\pm \mathrm{SD}(n=3)$. Using qRT-PCR, MP1 depletion was found to be approximately $90 \%$ (data not shown).

study reports for the first time evidence indicating that MP1 is involved in gastrin-mediated responses coupled to proliferation and possibly carcinogenesis.

MP1 was first identified to be a scaffold protein enhancing the efficiency of the MAPK pathway in response to serum stimulation in COS-1 cells (Schaeffer et al. 1998), and later, MP1 was shown to be involved in endosomal trafficking of EGF receptor and cell proliferation in mice (Teis et al. 2006). Further investigations on MP1 have also revealed its role in positive regulation of fibroblast cell 
spreading on fibronectin in vitro (Pullikuth et al. 2005). Our findings, demonstrating that MP1 is involved in gastrininduced phosphorylation of ERK1 and ERK2, are in keeping with previous findings on its molecular function in growth stimulatory responses (Pullikuth et al. 2005; Teis et al. 2006). Indeed, the observation that siRNA knockdown of MP1 induced G1 cell cycle arrest to a similar extent as the positive control, Cyclin D1, strongly suggests that MP1 is a positive regulator of gastrin-induced cell cycle entry. Taken together, our results indicate that gastrin-mediated activation of the MAPK pathway, which is known to be required for its induction of proliferation (Stepan et al. 1999), involves facilitation of the phosphorylation of ERK1 and/or ERK2 by MP1 scaffold activity.

Our finding that MP1 depletion induces cell cycle arrest completes the picture of MP1 as a significant factor in regulation of proliferation. Addition of gastrin increased the proportion of S-phase cells in siMP1-transfected cells, but not completely to the same level as in untreated siCtrtransfected samples. This finding underpinned the strong proliferation-inhibiting effect of MP1 depletion.

Recently, PAK1 was identified to be involved in gastrin signal transduction, as it was found to be required for gastrininduced activation of the $\beta$-catenin pathway (He et al. 2008). In addition, activation of the $\beta$-catenin pathway is shown to increase expression of genes like c-myc and Cyclin D1 (He et al. 1998; Shtutman et al. 1999). Taken together, the findings that PAK1 is involved in gastrin-mediated signaling and that MP1 regulates cell spreading via PAK1 signals (Pullikuth et al. 2005) suggest that PAK1 and MP1 may participate in the same pathway, integrating signals leading to gastrin-induced cellular responses. Further studies could therefore focus on the role of MP1 in gastrin-mediated signaling via PAK1 and other carcinogenesis-related processes.

MP1 was chosen for further studies due to its possible involvement in gastrin-induced responses linked to proliferation mainly by facilitating signaling via the MAPK pathway acting as a molecular scaffold. The roles of such specific interactions in the spatiotemporal organization of protein complexes seem to facilitate a fine-tuning of context-specific signaling. Further studies on MP1 could focus on further characterization of the detailed mechanisms in the scaffolding functions and its role in carcinogenic processes.

\section{Conclusion}

Our data shows that gastrin promotes cell proliferation in the human gastric adenocarcinoma cell line AGS- $G_{R}$ in a dosedependent manner. We show that gastrin induces transcription of a scaffold protein, MP1, both in the neuroendocrine pancreatic cell line AR42J and AGS- $G_{R}$ cells. Our results highlight that MP1 is important for gastrin-induced phosphorylation of ERK1 and ERK2, and that MP1 promotes gastrin-induced proliferation. Taken together, our data suggest a new role for MP1 in regulation of cellular proliferation, and our findings are in keeping with MP1 as a scaffold protein promoting MAPK signaling pathway flux and suggest new insights into some of the complex mechanisms of tumorigenesis.

Acknowledgements We thank Professor Andrew Catling at Louisiana State University School of Medicine in New Orleans for the MP1 antibody. We also thank Hanne Hella at the Department of Cancer Research and Molecular Medicine (NTNU) for skillful technical assistance on the flow cytometry experiments.

Grants This work was funded by the Norwegian University of Science and Technology (NTNU), Sør-Trøndelag University College, The Norwegian Cancer Society, and The Liaison Committee between the Central Norway Regional Health Authority (RHA) and NTNU.

Disclosures The authors declare that they have no conflict of interest.

Open Access This article is distributed under the terms of the Creative Commons Attribution License which permits any use, distribution, and reproduction in any medium, provided the original author(s) and the source are credited.

\section{References}

Baldin V.; Lukas J.; Marcote M. J.; Pagano M.; Draetta G. Cyclin D1 is a nuclear protein required for cell cycle progression in G1. Genes Dev 7: 812-21; 1993.

Bestervelt L.; Barr B.; Dethloff L. Divergent proliferative responses to a gastrin receptor ligand in synchronized and unsynchronized rat pancreatic AR42J tumour cells. Cell Signal 12: 53-61; 2000.

Detjen K.; Fenrich M. C.; Logsdon C. D. Transfected cholecystokinin receptors mediate growth inhibitory effects on human pancreatic cancer cell lines. Gastroenterology 112: 952-9; 1997a.

Detjen K.; Yule D.; Tseng M. J.; Williams J. A.; Logsdon C. D. CCK-B receptors produce similar signals but have opposite growth effects in CHO and Swiss 3 T3 cells. Am J Physiol 273: C1449-57; $1997 b$.

Dimaline R.; Varro A. Attack and defence in the gastric epithelium-a delicate balance. Exp Physiol 92: 591-601; 2007.

Dockray G.; Dimaline R.; Varro A. Gastrin: old hormone, new functions. Pflugers Arch 449: 344-55; 2005.

Dockray G. J.; Varro A.; Dimaline R.; Wang T. The gastrins: their production and biological activities. Annu Rev Physiol 63: 119 39; 2001.

Edkins J. S. The chemical mechanism of gastric secretion. J Physiol 34: 133-44; 1906.

Fjeldbo C. S.; Bakke I.; Erlandsen S. E.; Holmseth J.; Laegreid A.; Sandvik A. K.; Thommesen L.; Bruland T. Gastrin upregulates the prosurvival factor secretory clusterin in adenocarcinoma cells and in oxyntic mucosa of hypergastrinemic rats. Am J Physiol Gastrointest Liver Physiol 302: G21-33; 2012.

Grabowska A. M.; Watson S. A. Role of gastrin peptides in carcinogenesis. Cancer Lett 257: 1-15; 2007.

He H.; Shulkes A.; Baldwin G. S. PAK1 interacts with betacatenin and is required for the regulation of the beta- 
catenin signalling pathway by gastrins. Biochim Biophys Acta 1783: 1943-54; 2008.

He T. C.; Sparks A. B.; Rago C.; Hermeking H.; Zawel L.; da Costa L. T.; Morin P. J.; Vogelstein B.; Kinzler K. W. Identification of c-MYC as a target of the APC pathway. Science 281: 1509-12; 1998.

Hill C. S.; Treisman R. Transcriptional regulation by extracellular signals: mechanisms and specificity. Cell 80: 199-211; 1995.

Hofsli E.; Thommesen L.; Norsett K.; Falkmer S.; Syversen U.; Sandvik A.; Laegreid A. Expression of chromogranin A and somatostatin receptors in pancreatic AR42J cells. Mol Cell Endocrinol 194: 165-73; 2002.

Ishizuka J.; Martinez J.; Townsend Jr. C. M.; Thompson J. C. The effect of gastrin on growth of human stomach cancer cells. Ann Surg 215: 528-34; 1992.

Koh T. J.; Goldenring J. R.; Ito S.; Mashimo H.; Kopin A. S.; Varro A.; Dockray G. J.; Wang T. C. Gastrin deficiency results in altered gastric differentiation and decreased colonic proliferation in mice. Gastroenterology 113: 1015-25; 1997.

Kozar K.; Sicinski P. Cell cycle progression without cyclin D-CDK4 and cyclin D-CDK6 complexes. Cell Cycle 4: 388-91; 2005.

Livak K. J.; Schmittgen T. D. Analysis of relative gene expression data using real-time quantitative PCR and the 2(-Delta Delta $\mathrm{C}(\mathrm{T})$ ) method. Methods 25: 402-8; 2001.

Muerkoster S.; Isberner A.; Arlt A.; Witt M.; Reimann B.; Blaszczuk E.; Werbing V.; Folsch U. R.; Schmitz F.; Schafer H. Gastrin suppresses growth of CCK2 receptor expressing colon cancer cells by inducing apoptosis in vitro and in vivo. Gastroenterology 129: 952-68; 2005.

Noble P. J.; Wilde G.; White M. R.; Pennington S. R.; Dockray G. J.; Varro A. Stimulation of gastrin-CCKB receptor promotes migration of gastric AGS cells via multiple paracrine pathways. Am J Physiol Gastrointest Liver Physiol 284: G75-84; 2003.

Nada S.; Hondo A.; Kasai A.; Koike M.; Saito K.; Uchiyama Y.; Okada M. The novel lipid raft adaptor p18 controls endosome dynamics by anchoring the MEK-ERK pathway to late endosomes. Embo J 28: 477-89; 2009.

Pullikuth A.; McKinnon E.; Schaeffer H. J.; Catling A. D. The MEK1 scaffolding protein MP1 regulates cell spreading by integrating PAK1 and Rho signals. Mol Cell Biol 25: 5119-33; 2005.

Schaeffer H. J.; Catling A. D.; Eblen S. T.; Collier L. S.; Krauss A.; Weber M. J. MP1: a MEK binding partner that enhances enzymatic activation of the MAP kinase cascade. Science 281: 1668$71 ; 1998$.

Seufferlein T.; Withers D. J.; Broad S.; Herget T.; Walsh J. H.; Rozengurt $\mathrm{E}$. The human $\mathrm{CCKB} /$ gastrin receptor transfected into rat1 fibroblasts mediates activation of MAP kinase, p74raf-1 kinase, and mitogenesis. Cell Growth Differ 6: 383-93; 1995.

Seva C.; De Vries L.; Scemama J. L.; Sarfati P.; Nicolet T. G.; Pradayrol L.; Vaysse N. Gastrin modulates growth of a rat acinar pancreatic cell line: receptor analysis and signal transduction. Digestion 46(Suppl 2): 166-9; 1990.

Shtutman M.; Zhurinsky J.; Simcha I.; Albanese C.; D'Amico M.; Pestell R.; Ben-Ze'ev A. The cyclin D1 gene is a target of the beta-catenin/ LEF-1 pathway. Proc Natl Acad Sci USA 96: 5522-7; 1999.

Smith J. P.; Kramer S. T.; Demers L. M. Effects of gastrin and difluoromethylornithine on growth of human colon cancer. Dig Dis Sci 38: 520-8; 1993.
Smith J. P.; Liu G.; Soundararajan V.; McLaughlin P. J.; Zagon I. S. Identification and characterization of CCK-B/gastrin receptors in human pancreatic cancer cell lines. Am J Physiol 266: R277-83; 1994.

Steigedal T. S.; Bruland T.; Misund K.; Thommesen L.; Laegreid A. Inducible cAMP early repressor suppresses gastrin-mediated activation of cyclin D1 and c-fos gene expression. Am J Physiol Gastrointest Liver Physiol 292: G1062-G1069; 2007.

Stepan V. M.; Dickinson C. J.; del Valle J.; Matsushima M.; Todisco A. Cell type-specific requirement of the MAPK pathway for the growth factor action of gastrin. Am J Physiol 276: G1363-72; 1999.

Teis D.; Taub N.; Kurzbauer R.; Hilber D.; de Araujo M. E.; Erlacher M.; Offterdinger M.; Villunger A.; Geley S.; Bohn G.; Klein C.; Hess M. W.; Huber L. A. p14-MP1-MEK1 signaling regulates endosomal traffic and cellular proliferation during tissue homeostasis. J Cell Biol 175: 861-868; 2006.

Teis D.; Wunderlich W.; Huber L. A. Localization of the MP1-MAPK scaffold complex to endosomes is mediated by $\mathrm{p} 14$ and required for signal transduction. Dev Cell 3: 803-14; 2002.

Todisco A.; Ramamoorthy S.; Witham T.; Pausawasdi N.; Srinivasan S.; Dickinson C. J.; Askari F. K.; Krametter D. Molecular mechanisms for the antiapoptotic action of gastrin. Am J Physiol Gastrointest Liver Physiol 280: G298-307; 2001.

Todisco A.; Takeuchi Y.; Seva C.; Dickinson C. J.; Yamada T. Gastrin and glycine-extended progastrin processing intermediates induce different programs of early gene activation. $J$ Biol Chem 270: 28337-41; 1995.

Varro A.; Noble P. J.; Wroblewski L. E.; Bishop L.; Dockray G. J. Gastrin-cholecystokinin(B) receptor expression in AGS cells is associated with direct inhibition and indirect stimulation of cell proliferation via paracrine activation of the epidermal growth factor receptor. Gut 50: 827-33; 2002.

Vindelov L. L.; Christensen I. J.; Nissen N. I. A detergent-trypsin method for the preparation of nuclei for flow cytometric DNA analysis. Cytometry 3: 323-7; 1983.

Wang T. C.; Dangler C. A.; Chen D.; Goldenring J. R.; Koh T.; Raychowdhury R.; Coffey R. J.; Ito S.; Varro A.; Dockray G. J.; Fox J. G. Synergistic interaction between hypergastrinemia and Helicobacter infection in a mouse model of gastric cancer. Gastroenterology 118: 36-47; 2000.

Wang T. C.; Koh T. J.; Varro A.; Cahill R. J.; Dangler C. A.; Fox J. G.; Dockray G. J. Processing and proliferative effects of human progastrin in transgenic mice. J Clin Invest 98: 191829; 1996.

Watson F.; Kiernan R. S.; Deavall D. G.; Varro A.; Dimaline R. Transcriptional activation of the rat vesicular monoamine transporter 2 promoter in gastric epithelial cells: regulation by gastrin. $J$ Biol Chem 276: 7661-71; 2001.

Watson S. A.; Grabowska A. M.; El-Zaatari M.; Takhar A. Gastrinactive participant or bystander in gastric carcinogenesis? Nat Rev Cancer 6: 936-46; 2006.

Wroblewski L. E.; Pritchard D. M.; Carter S.; Varro A. Gastrinstimulated gastric epithelial cell invasion: the role and mechanism of increased matrix metalloproteinase 9 expression. Biochem $J$ 365: 873-9; 2002.

Yassin R. R. Signaling pathways mediating gastrin's growth-promoting effects. Peptides 20: 885-98; 1999. 